\title{
Lack of Proper Technical Gadgets for Authority Personnels in Chennai
}

\author{
G. Anandhi, T. Subha Latha, S. Jenifer Vinnarasi
}

\begin{abstract}
Due to its negative impact on the individual and the organization, pressure is a widespread problem. This study's course is to identify the causes of stress and also to study the effect of socio-demographic variables influencing the levels of stress among female constables. Women's main sources of stress include the complexities of the work environment, ever-pressure, work-life balance, and job fatigue in the police profession. Stress levels were studied using the scale of the police Stress Inventory to identify the stressors of the organization and operational stressors. The stress attributes are identified as the main stressors, namely, excessive job demands, lack of organizational resources, policy changes / interventions, sudden organizational change, less likelihood of advancing illness and sudden health issues assigning additional responsibility. In terms of socio-demographic factors, the research leads to recognizing the work stress factors that female police constables are feeling.
\end{abstract}

Keywords: Ever pressure, Tension, anxiety, Media, Overtime

\section{INTRODUCTION}

It is unclear the source of the word "stress." It is a common term that in the 14th century came to be used. It meant physical hardship, hunger, torture, and strain experiences. Nevertheless, the term nowadays revolves around the medieval meaning, where "pressure" simply means "hardship." We are told by recent scientific advances that "pressure" is really great for us [1]-[4]. Stress is derived from the Latin word stranger, which means drawing near, and was used in the 17th century to describe rough ship or affliction. Stress denoted force, pressure, strain or strong effort during the late 18th century, referring primarily to an individual or to the organs or mental owners of an individual. Stress happens when people feel that they can't adapt adequately to their solicitations or dangers to their prosperity. Stress results from an interest asset lopsidedness. Stress is the manner in which the body reacts to any condition, and it can truly influence the life of an individual[13]-[19]. However the significance of stress the executives in their lives isn't comprehended by individuals. Great supervisors ought to stay responsible forever, even in unpleasant circumstances, without freezing. Through planning assignments, making normal breaks and restoring them, they oversee pressure

Revised Manuscript Received on December 11, 2019

G. Anandhi, Department of Science and Humanities, Bharath Institute of Higher Education and Research, Chennai , India Email: anandhi5679@gmail.com

T. Subha Latha, Department of Science and Humanities, Bharath Institute of Higher Education and Research, Chennai , India Email: subhalatha.thavasikannan@gmail.com

S. Jenifer Vinnarasi, Department of Science and Humanities, Bharath Institute of Higher Education and Research, Chennai, India Email: mjjaa24@gmail.com

\section{OBJECTIVES}

1. Identify the personal factors that cause tension among staff 2. To analyze the departmental factors leading to stress among the executives.

3. To study the work related factors creating stress.

\section{A. Limitations}

1. The study has the scope of analyzing the reception of personnel regarding stress with personal revelations.

2. Different classifications of the respondents explain the scope of stress severity, stress management in the respective branches of the department

\section{RESULTS AND DISCUSSIONS}

\section{A. Meaning and Definition of stress}

The word pressure is characterized by the Oxford Dictionary as "a condition of issue including request on physical or mental vitality". It is a condition or conditions (not constantly antagonistic), which can upset the typical physical and emotional wellness of a person. Hans Sale, (1936) the dad of stress has characterized worry as a "vague reaction of the body to any requests made upon it"[5]-[6]

\section{B. Nature of Stress}

Hans Sale (1936) the dad of stress said that pressure is the since of life and nonattendance of stress is passing. Without worry, there would be no life. Stress isn't in every case essentially hurtful[7]-[8]. He says, "Stress isn't really something awful. Everything relies upon how you take it" Stress can be in this way negative, positive or nonpartisan. As a positive impact, stress can damnation and comes us to activity. It can bring about mindfulness and an energizing new particular. As a negative impact, it can bring about sentiments of misery, dismissal outrage and discouragement which thusly can prompt medical issues, for example, cerebral pains, stomach upsets, rashes, sleep deprivation, ulcers, high blood consoles, coronary illness and stroke.

\section{Work Stress}

Work pressure is a unique condition where an individual stands up to with a fortuity, requirement or request identified with what the person in question wants and for which the result is gotten to be both sure and significant.

\section{Stress Management}

Stress management has a constructive way of dealing with pressure to ensure good health and well-being. While pressure is unavoidable in a changing world, there are ways for executives to handle it. 
Stress management includes regular rest, physical exercise, interaction with others, space for social activities, and fair self-declaration. Workers need to identify the need for stress management and develop strategies to reduce the impact of disruptive changes at work in order to handle change[9]-[12]. Making improvements at work and learning to reduce stress would allow employees to act more efficiently and adapt. Stress management lets managers come in when change is in danger of becoming unbearable. Ideally, one needs transition to happen in a structured way that allows one to remain calm, confident and hopeful. Stress can cause an individual, as well as the organization, unpredictable and unmeasurable problems. It can cause job-related problems such as negating safety standards, indifferent job performance, quality compromises, disregard for others and the environment, forgetfulness, uncharacteristic clumsiness, defiant authority, defensiveness and violent behaviour.

\section{CONCLUSION}

The investigation disclosed Stress because of deficient individual time, Seeing lawbreakers going free, Lack of acknowledgment for good work, Having to go to court, Having to manage the media, Meeting cutoff times, Working extra time, Dealing with emergency circumstances, Lack of fortuity for progression, Competition for headway Inadequate compensation, Delivering a demise message or awful news are the essential drivers of worry among constables. Further, it observationally examined that age, sexual orientation, religion, administration of the years, conjugal status, salary and the spot of living arrangement in a similar field has critical relationship with feeling of anxiety among constables. The investigation proposes to normally sorting out the preparation projects, advising and therapeutic checkups for stress the executives of ladies constables.

\section{REFERENCES}

1. Vasanthi, S. \& Rabiyathul Basariya, S. 2019, "Influence of value analysis and cross training in industry", International Journal of Engineering and Advanced Technology, vol. 8, no. 6, pp. 1810-1811.

2. Velvizhi, R., Sri Gowtham, S. \& Jeya Priya, D. 2019, "Examination of early feedbacks for effective product retailing on E-commerce websites", International Journal of Engineering and Advanced Technology, vol. 8, no. 6 Special Issue 2, pp. 703-706.

3. Anuradha, C., Pothumani, S. \& Kavitha, R. 2019, "A novel method towards E-commerce", International Journal of Engineering and Advanced Technology, vol. 8, no. 6 Special Issue 2, pp. 535-538.

4. Thomas, J. \& Rabiyathul Basariya, S. 2019, "A study on the issues of financial ratio analysis", Indian Journal of Public Health Research and Development, vol. 10, no. 3, pp. 1079-1081.

5. Ramachandran, S. \& Rabiyathul Basariya, S. 2019, "Online marketing study on customer satisfaction and relationship", Indian Journal of Public Health Research and Development, vol. 10, no. 3, pp. 1072-1078.

6. Priya, R., Vinothini, G. \& Cor Jesu, C.D. 2019, "The mentor-protégé relationship for professional growth", Journal of Advanced Research in Dynamical and Control Systems, vol. 11, no. 9 Special Issue, pp. 1110-1119.

7. Jannifer Rani, N., Bina Pani, S. \& Nimisha, N.S. 2019, "A study on money back polices available in LIC", Journal of Advanced Research in Dynamical and Control Systems, vol. 11, no. 9 Special Issue, pp. 833-839.

8. Saillaja, V., Jhansi Rani, K. \& Catherine, R. 2019, "Global marketing management planning and organization", Journal of Advanced Research in Dynamical and Control Systems, vol. 11, no. 9 Special Issue, pp. 489-493.

9. Saillaja, V., Jhansi Rani, K. \& Catherine, R. 2019, "The new phase of marketing information system", Journal of Advanced Research in Dynamical and Control Systems, vol. 11, no. 9 Special Issue, pp. 482-488.
10. Thoufiqulla \& Raju, D.V. 2019, "Perception of indian investor towards investment in mutual funds with special reference to mip funds", Journal of Advanced Research in Dynamical and Control Systems, vol. 11, no. 5, pp. 177-183.

11. Jasmine, K.R.M. \& Basariya, S.R. 2018, "A study on the customers benefits on mutual funds", International Journal of Civil Engineering and Technology, vol. 9, no. 4, pp. 45-48

12. Vasanthi, S. \& Basariya, S.R. 2019, "Pros and cons of on the job training versus off the job training", International Journal of Scientific and Technology Research, vol. 8, no. 10, pp. 671-674.

13. Pavithra, J. \& Ganesan, M. 2016, "A study on awareness and impact of micro-financial schemes", International Journal of Applied Business and Economic Research, vol. 14, no. 8, pp. 5449-5460.

14. Pavithra, J., Dilli Babu, P. \& Ambuli, T.V. 2014, "A study on budgetary control at Maruti Service Masters, Chennai", International Journal of Applied Business and Economic Research, vol. 12, no. 2, pp. 151-161.

15. Gunaraja, T.M. \& Venkatrama Raju, D. 2018, "Determining factors of organisational climate with reference to leadership styles", International Journal of Mechanical Engineering and Technology, vol. 9, no. 9, pp. 1327-1332.

16. Gunaraja, T.M. \& Venkatrama Raju, D. 2018, "The role of job satisfaction and training of employees in determining organisational climate of a selected industry", International Journal of Civil Engineering and Technology, vol. 9, no. 8, pp. 1266-1269.

17. Aarathy, T.S. \& Raju, D.V. 2018, "Performance appraisal and its effects on employees with respect to it sector in Chennai city", International Journal of Civil Engineering and Technology, vol. 9, no. 6, pp. 1535-1538.

18. Aarathy, T.S. \& Raju, D.V. 2018, "Employee perception towards performance appraisal system in IT sector", International Journal of Mechanical Engineering and Technology, vol. 9, no. 5, pp. 131-135.

19. Porselvi, W., Jublee, D. \& Sivanesan, G. 2018, "A study on factors influencing adoption of technology and innovation in banking industry, tamilnadu, India", International Journal of Mechanical Engineering and Technology, vol. 9, no. 5, pp. 789-800.

20. Akessa, G.M. and Dhufera, A.G., 2015. Factors That Influences Students Academic Performance: A Case of Rift Valley University, Jimma, Ethiopia. Journal of Education and Practice, 6(22), pp.55-63.

21. Miller, G. and Shih, C.C., 1999. A faculty assessment of the academic rigor of on-and off-campus courses in agriculture. Journal of Agricultural Education, 40, pp.57-65.

22. Tsinidou, M., Gerogiannis, V. and Fitsilis, P., 2010. Evaluation of the factors that determine quality in higher education: an empirical study. Quality Assurance in education, 18(3), pp.227-244.

23. Farooq, M.S., Chaudhry, A.H., Shafiq, M. and Berhanu, G., 2011 Factors affecting students' quality of academic performance: a case of secondary school level. Journal of quality and technology management, 7(2), pp.1-14.

24. Fitsilis, P., Gerogiannis, V. and Anthopoulos, L., 2014. Ontologies for software project management: a review. Journal of Software Engineering and Applications, 7(13), p.1096.

25. Adams, J.D. and Jaffe, A.B., 1996. Bounding the effects of R\&D: an investigation using matched establishment-firm data(No. w5544). National bureau of economic research.

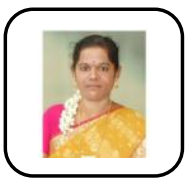

\section{AUTHORS PROFILE}

G. Anandhi Assistant Professor, Department of Science and Humanities, Bharath Institute of Higher Education and Research, Chennai, India.

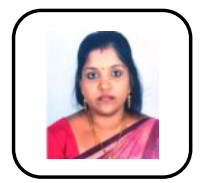

T. Subha Latha Assistant Professor, Department of Science and Humanities, Bharath Institute of Higher Education and Research, Chennai, India.

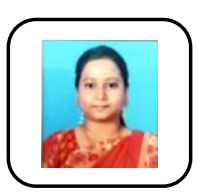

S. Jenifer Vinnarasi Assistant Professor, Departmen of Science and Humanities, Bharath Institute of Higher Education and Research, Chennai, India. 